\title{
Impact of stroke etiology on clinical symptoms and functional status
}

\author{
Ozge Gulsum Memetoglu, Aslihan Taraktas, Naciye Bilgin Badur, Feyza Unlu Ozkan \\ Department of Physical Medicine and Rehabilitation, Fatih Sultan Mehmet Training and Research Hospital, Istanbul, Turkey
}

\begin{abstract}
OBJECTIVE: The aim of this study is to investigate the differences between hemorrhagic and ischemic stroke patients in terms of clinical and functional features.

METHODS: Medical records of the patients with stroke were analyzed retrospectively. The patients' demographic characteristics, stroke etiology, time interval after the event, comorbid illness and functional status were recorded.

RESULTS: The stroke etiology was ischemia for 60 (36 male/24 female) (75\%) patients, and haemorrhage for 20 (10 male/10 female) (25\%) patients. Patients with ischemic stroke were classified as Group 1, and patients with hemorrhagic stroke were classified as Group 2. The mean age for Group 1 was $62.2 \pm 13.2$, and $55.8 \pm 17.1$ years for Group 2 ( $p=0.592)$. In Group 1, $33(55 \%)$ patients, and in Group 2, $11(55 \%)$ patients were primary school graduates $(p=0.984)$. Localization of the lesion was in the right side for $33(55 \%)$ patients in Group 1 , and for $15(75 \%)$ patients in Group $2(p=0.372)$. The mean time interval after event for Group 1 was 7 months $(0-211$ days), and for Group 2 it was 14.5 (1-420 days) months ( $p=0.592$ ). FIM score for Group 1 was $71.9 \pm 28.0$, and $68.1 \pm 21.0$ for Group 2 ( $p=0.575)$. The mean Brunnstrom score for upper extremity was 3.5 for Group 1,3 for Group 2, ( $p=0.866)$, and for lower extremity, it was 3.5 for Group 1, and 3 for Group 2 ( $p=0.143$ ). Spasticity was present in 45 (75\%) patients in Group 1, and in $12(60 \%)$ patients in Group $2(p=0.311)$. In Group $151(85 \%)$ of the patients and $18(95 \%)$ patients had a history of comorbid disease $(p=0.554)$.
\end{abstract}

CONCLUSION: Etiology of stroke is thought to be not effective on the patient's clinical and functional status.

Key words: Hemorrhage, ischemia, stroke

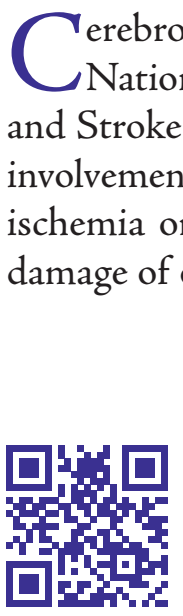

Received: August 10, 2014 Accepted: August 11, 2014 Online: December 08, 2014

Correspondence: Dr. Ozge Gulsum MEMETOGLU. Fatih Sultan Mehmet Egitim ve Arastirma Hastanesi, Fiziksel Tip ve Rehabilitasyon Bolumu, Istanbul, Turkey.

Tel: +90 216 - 5783000 e-mail: ozgeilleez@hotmail.com

(c) Copyright 2014 by Istanbul Northern Anatolian Association of Public Hospitals - Available online at www.kuzeyklinikleri.com

plying brain tissue [1]. Stroke ranks third among causes of mortality after heart disease, and cancer in developed countries. At the same time it ranks on top of the neurological diseases which cause mortality, and disability in adults [2]. Although geographic, racial, and ethnic differences are detect- 
ed, studies performed within the last two decades have demonstrated the incidence, and prevalence of stroke ranging between 1-3/1000, and 6/1000, respectively $[3,4]$. The incidence of stroke increases markedly with age, and for every decade after 55 years of age it rises twofold. It is more frequently seen in men rather than women [5]. Nearly $80 \%$ of the stroke patients require rehabilitation therapy [6]. Many factors including risk factors, concomitant diseases, location of the lesion, duration of rehabilitation, and severity of the lesion are effective on the outcomes of functional development, and rehabilitation therapy $[7,8]$.

In the literature studies performed on the outcomes of stroke patients, demographic information including gender, educational level, comorbid diseases, location, and extent of the lesion (if dominant hemisphere is involved), time elapsed after the incident, and history of the transient ischemic attack have been investigated [6, 8-12]. In our literature review, we have not encountered any study investigating whether etiological factors effect functional level of stroke patients. If the stroke etiology effects clinical findings and functional status independent from other factors, acceptance of the patients into rehabilitation services and schedule of rehabilitation programs can be determined according to the etiology of the patients' diseases. Therefore, with this study we aimed to investigate if any difference exists between hemorrhagic, and ischemic stroke patients as for clinical findings, and functional levels.

\section{MATERIALS AND METHODS}

Medical files of 80 stroke patients who consulted to Fatih Sultan Mehmet Training and Research Hospital were retrospectively investigated. Demographic information including gender, educational level, etiological factors for stroke, date of the incident, time elapsed after the incident, comorbid diseases, and functional status of the patients were recorded. For the evaluation of the functional state, functional independence measure (FIM) scale, and for the evaluation of functional motor recovery of upper, lower extremities, and hand, Brunnstrom staging was used. Spasticity was indicated with the terms 'present or absent'.

Statistical analysis was performed using SPSS 16.0 package program. Quantitative data were expressed as mean \pm standard deviation or median (minimum-maximum), and qualitative data as numerical values (numbers, and percentages). In intergroup comparisons qualitative data were evaluated using chi-square test, and quantitative data with Mann-Whitney U test.

\section{RESULTS}

Sixty (75\%) ischemic, and 20 (25\%) hemorrhagic stroke patients were investigated. Patients were classified as cases with ischemic (Group 1), and hemorrhagic (Group 2) stroke patients. Mean ages of the patients were 62.2 \pm 13.2 years in Group 1, and, $55.8 \pm 17.1$ years in Group $2(\mathrm{p}=0.592)$. Male patients constituted $60 \%(n=36)$, and $50 \%(n=50)$ of the total patient population in Groups 1, and 2, respectively $(\mathrm{p}=0.726)$. Primary school graduates in Groups $1(n=33 ; 55 \%)$, and $2(n=11 ; 55 \%)$ were also indicated $(p=0.984)$. Right-sided lesions were detected in a total of 48 patients (Group 1, $n=33$; $55 \% 55$, and Group 2, $n=15 ; 75 \%)(p=0.372)$. Median (range) duration of time elapsed after the incident was 7 (0-211 mos) months in Group 1 , and 14.5 (1-420 mos) months in Group 2 $(p=0.592)$. Mean FIM scores were $71.9 \pm 28.0$ in Group 1, and 68.1 \pm 21.0 in Group $2(p=0.575)$. Median Brunnstrom stages of recovery for upper (Group1, 3.5 and Group 2, 3; $p=0.866$ ), and lower extremities (Group 1: 3.5, and Group 2: 3; $p=0.143$ ), and hand (Group 1:2, and Group 2:2.5; $\mathrm{p}=0.827)$ were recorded. Spasticity was detected in 45 (75\%) Group 1, and 12 (60\%) Group 2 patients $(\mathrm{p}=0.311)$. Pre-existing comorbidities were revealed in 51 (85\%) Group 1, and 18 (95\%) Group 2 patients. Distribution of comorbitites did not differ between groups $(p=0.554)$. (hypertension: Group 1: 69.7\%, Group 2: 52\%; diabetes mellitus: Group 1: $32.2 \%$, and Group 2: $27.4 \%$; heart disease: Group 1, 23.8\%, and Group 2, 19.8\%). Comparative data related to patients' symptoms, and patient groups are given in Table 1 . 
TABLE 1. Intergroup comparisons

\begin{tabular}{lccc} 
& Group 1 (ischemic) $n=60$ & Group 2 (hemorrhagic) $n=20$ & $p$ \\
\hline Age (years) Mean \pm SD & $62.2 \pm 13.2$ & $55.8 \pm 17.1$ & 0.592 \\
Gender Female/Male $(n)$ & $24 / 36$ & $10 / 10$ & 0.726 \\
Location of the lesion & $33(55 \%)$ right & $15(75 \%)$ right & 0.372 \\
FIM score & $71.9 \pm 28.0$ & $68.1 \pm 21.0$ & 0.575 \\
Median Brunnstrom Stage & Upper extremity: 3.5 & Upper extremity: 3 & 0.866 \\
& Hand: 2 & Hand: 2.5 & 0.827 \\
Spasticity (present/absence) & Lower extremity: 3.5 & Lower extremity: 3 & 0.143 \\
Comorbid disease history and distribution & $45(75 \%)$ & $12(60 \%)$ & 0.311 \\
& & & \\
& $51(85 \%)$ & $18(95 \%)$ & 0.554
\end{tabular}

\section{DISCUSSION}

Stroke is quiet an important public health problem which ranks third after heart diseases, and cancer among causes of mortality, and it is on top of the causes of morbidity.

Therefore, many studies have been performed which investigated the etiology, demographic characteristics of patients, location, and extent of the lesion, and comorbid diseases [8-12]. Besides, in most of these studies the impact of these factors on the outcomes of rehabilitation therapy has been analyzed $[8$, 11]. However we haven't encountered any study in the medical literature which analysed functional state of the patient, and severity of clinical findings, and the impact of the hemorrhagic or ischemic stroke. We have looked into whether clinical findings, and functional state differ in patients with stroke of different etiologies, and we couldn't detect any difference between hemorrhagic, and ischemic stroke patients regarding demographic characteristics, clinical findings, and functional state of the patients.

Demographic characteristics of the patients can effect functional level of the patients. For example, incidence of stroke increases stepwise with aging
[6]. Though some studies have reported that age factor adversely effects functional state after an attack, some other studies suggested that it is not a major effective factor per se [13-16]. In a study performed by Hankey et al. 152 stroke patients were evaluated, and age factor was also reported among determinants of hospital stay, mortality, and disability 5 years after the onset of the stroke incident [10]. In the present study, mean age of our patients was $62.2 \pm 13.2$ years in Group 1, and 55.8 \pm 17.1 in Group 2. Our estimates for Group 1 were close to those reported in Aegean Stroke Database, while they were lower than our values for Group 2 [17]. In a study conducted by Bonita et al. between 19701985 with patients aged 40-69 years of age, higher post-stroke mortality rates were reported in male patients, while post-stroke recovery rates were relatively enhanced in female patients [18]. In a study by Hachisuka et al. although a significant difference was not detected in female, and male stroke patients as for motor function, among stroke patients FIM scores of the male patients were observedly lower than those of the female patients [19]. In our study, distribution of male, and female patients was not significantly different, despite general dominancy of the male gender. 
Hypertension, diabetes mellitus, hyperlipidemia, hyperuricemia, atrial fibrillation, heart failure, smoking, family history of stroke are among risk factors for stroke [20-23]. In our study, the most frequently (65\%) seen risk factor was hypertension. It was followed by diabetes mellitus (28\%), and heart disease $(27.2 \%)$. However between two diseases, distribution of comorbidities did not differ. In most of the studies performed, in support of our study, hypertension has been reported as the most important risk factor [5]. In one of the studies which investigated the impact of comorbid diseases on functional state, Giaquinto et al. detected a negative correlation between FIM scores, and severity of comorbid diseases [24]. Studies by Liu et al, and Karatepe et al. from our country also support this negative correlation [25-27].

Controversial outcomes have been retrieved from studies which investigated location, and severity of the lesion, and its functional level. According to the studies performed by Macciocchi et al. lesions located in the dominant hemisphere, and cortical level demonstrate more improved functional recovery [8]. In a study by Pantano et al. the authors could not detect a correlation between volume, and location of the lesion, severity of loss of motor functions, and whether ischemia involved the dominant hemisphere or not [12]. Since our study had a retrospective design, we couldn't access data on location, and severity of the lesions which is one of the deficiencies of our study.

One of the studies which investigated the impact of Brunnstrom stages, and spasticity levels on functional level 88 stroke patients were evaluated after completion of the rehabilitation program, and a positive correlation was seen between spasticity levels of the patients evaluated by Brunnstrum stages, Ashworth scale and measurements of the final functional state [28]. In the present study any difference was not detected between patients who experienced hemorrhagic, and ischemic stroke as for Brunnstrom motor recovery stages, and spasticity. Even though we hadn't any idea about location, and severity of the lesion, nearly similar clinical findings suggested that etiology of the stroke might not be very much effective on clinical symptoms.

Our inability to detect any difference between functional status of the patients suggests that the etiology is not very effective on the outcomes of the rehabilitation. In studies where the effect of lesion type on functional improvement in stroke rehabilitation was investigated, it has been observed that in patients who suffered from hemorrhagic stroke had generally worser functional levels at the onset, while these patients demonstrated better motor recovery after termination of the rehabilitation therapy relative to those with ischemic etiology [29]. Some of our patients were also included in the rehabilitation program. However we didn't either record pre-, and post-treatment FIM, Brunnstrom stage, and clinical information of the patients or compared levels of recovery in both groups which might be accepted as a limitation of our study.

In this study, since demographic data, comorbid diseases, time elapsed after the incident are not different between groups, we think that comparison of these two groups as for clinical, and functional perspectives is not inconvenient. However, with regression analysis, analyzing the effects on FIM scores, and clinical findings will enable achievement of more objective results. The outcomes of this study have demonstrated the necessity of performing more comprehensive retrospective analysis with higher number of patients.

In conclusion, although it is not possible to arrive at a definite conclusion, we have thought that the etiology of stroke has not any impact on clinical manifestations, and functional level. Therefore, we conceive that for stroke patients earlier, and more intensive physical therapy programs are not required on the basis of etiology. Therefore we think that there is no need to make a distinction, between different types of stroke patients for the purpose of implementation of earlier and intense rehabilitation programs.

Conflict of Interest: No conflict of interest was declared by the authors.

Financial Disclosure: The authors declared that this study has received no financial support.

\section{REFERENCES}

1. Special report from the National Institute of Neurological Dis- 
orders and Stroke. Classification of cerebrovascular diseases III. Stroke 1990;21:637-76. CrossRef

2. American Heart Association. Heart and Stroke Facts. Dallas, 1991.

3. Broderick JP, Phillips SJ, O'Fallon WM, Frye RL, Whisnant JP. Relationship of cardiac disease to stroke occurrence, recurrence, and mortality. Stroke 1992;23:1250-6. CrossRef

4. Kurtzke JF. Neuroepidemiology. Ann Neurol 1984;16:265-77.

5. Brandstater ME. İnme rehabilitasyonu In: Delisa AJ (Arasil T çeviri editörü) Fiziksel Tip ve Rehabilitasyon İlkeler ve Uygulamalar. Ankara: Güneş Tip Kitapevler 2007. p. 1655-76.

6. Doğan A, Nakipoğlu GF, Aslan DM, Kaya ZA, Ozgirgin N. The rehabilitation results of hemiplegic patients. Turk J Med Sci 2004;34:385-9.

7. Gündüz B. İnme ve prognozu etkileyen faktörler. Türk Fiz Tip Rehab Derg 2006;52:30-3.

8. Macciocchi SN, Diamond PT, Alves WM, Mertz T. Ischemic stroke: relation of age, lesion location, and initial neurologic deficit to functional outcome. Arch Phys Med Rehabil 1998;79:1255-7. CrossRef

9. Feigin VL, Wiebers DO, Nikitin YP, O'Fallon WM, Whisnant JP. Risk factors for ischemic stroke in a Russian community: a population-based case-control study. Stroke 1998;29:34-9. CrossRef

10. Hankey GJ, Jamrozik K, Broadhurst RJ, Forbes S, Anderson CS. Long-term disability after first-ever stroke and related prognostic factors in the Perth Community Stroke Study, 1989-1990. Stroke 2002;33:1034-40. CrossRef

11. Lin JH, Hsiao SF, Chang CM, Huang MH, Liu CK, Lin YT. Factors influencing functional independence outcome in stroke patients after rehabilitation. Kaohsiung J Med Sci 2000;16:351-9.

12. Pantano P, Formisano R, Ricci M, Di Piero V, Sabatini U, Di Pofi $\mathrm{B}$, et al. Motor recovery after stroke. Morphological and functional brain alterations. Brain 1996;119:1849-57. CrossRef

13. Suputtitada A, Aksaranugraha S, Granger CV, Sankaew M. Results of stroke rehabilitation in Thailand. Disabil Rehabil 2003;25:1140-5. CrossRef

14. Ingall T. Stroke--incidence, mortality, morbidity and risk. J Insur Med 2004;36:143-52.

15. Chiou-Tan FY, Keng MJ Jr, Graves DE, Chan KT, Rintala DH. Racial/ethnic differences in FIM scores and length of stay for underinsured patients undergoing stroke inpatient rehabilita- tion. Am J Phys Med Rehabil 2006;85:415-23. CrossRef

16. Lin JH, Hsieh CL, Lo SK, Hsiao SF, Huang MH. Prediction of functional outcomes in stroke inpatients receiving rehabilitation. J Formos Med Assoc 2003;102:695-700.

17. Kumral E, Ozkaya B, Vardarlı E, Sağduyu A, Şirin H, Pehlivan M. Ege İnme Veri Tabanı. Ege bolgesinde hastane tabanlı calışma 2000 inme hastasının analizi. Turk Norol Derg 1997;1-2:3-12.

18. Bonita R, Stewart A, Beaglehole R. International trends in stroke mortality: 1970-1985. Stroke 1990;21:989-92. CrossRef

19. Hachisuka K, Tsutsui Y, Furusawa K, Ogata H. Gender differences in disability and lifestyle among community-dwelling elderly stroke patients in Kitakyushu, Japan. Arch Phys Med Rehabil 1998;79:998-1002. CrossRef

20. Dalyan M, Çakçı A. İnme rehabilitasyonu In: Oğuz H, Dursun E, Dursun N, editörler. Tibbi Rehabilitasyon. İstanbul: Nobel tıp kitapevleri 2004; p. 589-618.

21. Hankey GJ. Potential new risk factors for ischemic stroke: what is their potential? Stroke 2006;37:2181-8. CrossRef

22. Sanossian N, Ovbiagele B. Multimodality stroke prevention. Neurologist 2006;12:14-31. CrossRef

23. Dimitroula HV, Hatzitolios AI, Karvounis HI. The role of uric acid in stroke: the issue remains unresolved. Neurologist 2008; 14:238-42. CrossRef

24. Giaquinto S. Comorbidity in post-stroke rehabilitation. Eur J Neurol 2003;10:235-8. CrossRef

25. Liu M, Domen K, Chino N. Comorbidity measures for stroke outcome research: a preliminary study. Arch Phys Med Rehabil 1997;78:166-72. CrossRef

26. Liu M, Tsuji T, Tsujiuchi K, Chino N. Comorbidities in stroke patients as assessed with a newly developed comorbidity scale. Am J Phys Med Rehabil 1999;78:416-24. CrossRef

27. Karatepe AG, Gunaydin R, Kaya T, Turkmen G. Comorbidity in patients after stroke: impact on functional outcome. J Rehabil Med 2008;40:831-5. CrossRef

28. Oneş K, Yalçinkaya EY, Toklu BC, Cağlar N. Effects of age, gender, and cognitive, functional and motor status on functional outcomes of stroke rehabilitation. NeuroRehabilitation 2009;25:241-9.

29. Kelly PJ, Furie KL, Shafqat S, Rallis N, Chang Y, Stein J. Functionalrecovery following rehabilitation after hemorrhagic and ischemic. Stroke 2003;34:2861-5. 